\title{
Characteristics of water isotopes and hydrograph separation during the spring flood period in Yushugou River basin, Eastern Tianshans, China
}

\author{
Xiaoyan Wang ${ }^{1, *}$, Zhongqin Li ${ }^{1,2}$, Edwards Ross ${ }^{3}$, RuOzihan TAYieR $^{4}$ and Ping Zhou ${ }^{1}$ \\ ${ }^{1}$ State Key Laboratory of Cryosphere Sciences/Tianshan Glaciological Station, Cold and Arid Regions \\ Environmental and Engineering Research Institute, Chinese Academy of Sciences, Lanzhou 730000, Gansu, China. \\ ${ }^{2}$ College of Geography and Environmental Science, Northwest Normal University, Lanzhou 730070, Gansu, China. \\ ${ }^{3}$ Imaging and Applied Physics, Curtin University of Technology, Bentley WA 6102, Australia. \\ ${ }^{4}$ Hami Hydrology and Water Resources Survey Bureau, Hami 839000, Xinjiang, China. \\ ${ }^{*}$ Corresponding author. e-mail: wangxiaoyan_84@163.com
}

\begin{abstract}
Many of the river basins in northwest China receive water from melting glaciers and snow in addition to groundwater. This region has experienced a significant change in glacier and snowpack volume over the past decade altering hydrology. Quantifying changes in water resources is vital for developing sustainable strategies in the region. During 2013, a water-isotope source apportionment study was conducted during the spring flood in the Yushugou River basin, northwestern China. The study found significant differences in water isotopes between river water, snowmelt water, and groundwater. During the study period, the isotopic composition of groundwater remained relatively stable. This stability suggests that the groundwater recharge rate has not been significantly impacted by recent hydro-climatic variability. The river water flow rate and water $\delta^{18} \mathrm{O}$ displayed an inverse relationship. This relationship is indicative of snowmelt water injection. The relative contribution of the two sources was estimated using a twocomponent isotope hydrograph separation. The contribution of snowmelt water and groundwater to Yushugou River were $\sim 63 \%$ and $\sim 37 \%$, respectively. From the study, we conclude that snowmelt water is the dominant water source to the basin during the spring melt period.
\end{abstract}

\section{Introduction}

A shortage of water resources in cold and arid regions presents a significant problem for their rational utilization. Understanding the water cycle in these regions is thus vital for their sustainability. Water derived from alpine glaciers and snow packs are essential for a large portion of the global population. At present, global warming is increasing the volume of melt water from glacier and mountain snowpack sources (Kong and Pang 2012). However, under sustained global warming this source of water will decrease as glaciers disappear and the seasonal snowpacks move to higher altitudes. Water source apportionment studies are needed to quantify the evolution of hydrology in these regions.

Due to some of the thermodynamic properties of water molecules, which are related to the quality of hydrogen and oxygen atoms, the process of water circulation leads to the hydrogen and oxygen stable isotope fractionation. Stable water isotope fractionation has been used by a number of studies to investigate the past and present water cycle of atmospheric precipitation (Dansgaard 1964; Price et al. 2008), groundwater (Song et al. 1999;

Keywords. Stable isotopes; hydrograph separation; Yushugou River basin. 
Harrington et al. 2002), ice and snow (Moser and Stichler 1980; Raben and Theakstone 1995; He et al. 2001), and surface runoff (Theakstone and Knudsen 1996; Kendall et al. 2001). Previous studies show that components of surface water may include surface flow, subsurface water, melt water, and ground water and their contribution is sitedependent (e.g., Buttle 1994; Liu et al. 2008a, b). The premise and necessary condition of using isotope to research water cycle is to study the isotopic distribution characteristics in different water bodies. In particular, the stable isotopes oxygen 18 $\left({ }^{18} \mathrm{O}\right)$ and deuterium (D) have been used to study dynamic processes (Guo et al. 1994; Fan and Ma 2000) and lay the formation and evolution of water bodies (Zhang et al. 2006). There has been plenty of research showing that differences in the stable isotope composition of different water sources can be leveraged to estimate source contributions to water bodies (Buttle 1994; Liu et al. 2008a, b; Kong and Pang 2012; $\mathrm{Pu}$ et al. 2012). Isotopic hydrograph separation is an effective method for the catchment-scale source contribution estimation (Dincer et al. 1970; Fritz et al. 1976; Kendall 1993; Mortathi et al. 1997). Recently, isotopic hydrograph separation methods have been applied to source apportionment in alpine valleys (Hoeg et al. 2000; Blume et al. 2008; Liu et al. 2008a, b; Zhang et al. 2008). Gu (1993) used ${ }^{18} \mathrm{O}$ as the dividing factor to investigate in contributions to the Urumqi River in northwestern China. The study finds that groundwater and snow/glacier melt water are the main sources of water to the Urumqi River. Kong and Pang (2012) found that the Urumqi River discharge contained less than $9 \%$ of snow/glacier melt water, while the Kumalak River (northwestern China) comprised more than $57 \%$ snow/glacier melt water. A two-component hydrograph separation has been performed in the Baishui catchment in the Mt. Yulong region of southwestern China. The study finds that during the wet season $\sim 53 \%$ of the water discharge comes from snow/glacier melt water and the remaining $47 \%$ from precipitation ( $\mathrm{Pu}$ et al. 2012).

The Yushugou River basin with less than average annual rainfall, located in the arid northwest China, is an important water resource for Hami area. The river basin originates from the eastern Tianshan Mountains which contribute snowmelt water. Existing research (Ma and Luo 2009) shows that rising temperatures in the region correlate to increasing river flow. Previous studies of this area are mainly limited to research of hydrological features, such as rainfall, runoff, floods, and sediment transport (Luo et al. 2002; Ma and Luo 2009; Zhang and Liu 2011). However, little is known with regard to water source contribution. To investigate water source contributions, stable isotope samples of river water, groundwater, and snowmelt water were collected during the 2013 spring flood period. The objectives of this study are: (1) to document the characteristics of ${ }^{18} \mathrm{O}$ and $\mathrm{D}$ in river water, groundwater, and snowmelt water; and (2) to determine various components contributing to runoff during the spring flood period, especially the snowmelt water contribution. The results are expected to provide an insight into water resources and watershed management in the area.

\section{Study area}

The Yushugou River basin $\left(93^{\circ} 57^{\prime}-94^{\circ} 19^{\prime} \mathrm{E}\right.$, $\left.43^{\circ} 02^{\prime}-43^{\circ} 11^{\prime} \mathrm{N}\right)$ is located in the eastern Tianshan Mountains at the southern slope of Harlik Range. The downstream portion of the basin is close to the Hami basin, and lies between the Guxiang River basin in west and Miaoergou basin in east. The whole basin is in Hami Prefecture, Xinjiang. The only hydrological station in the river basin, Yushugou Hydrometric Station, is located at an altitude of $1670 \mathrm{~m}$ above sea level (a.s.l), and the catchment area above the station is $308 \mathrm{~km}^{2}$. The average slope of the basin is $38.2 \%$, and the average altitude is $3091 \mathrm{~m}$ a.s.l.

Glaciers and permanent snow cover are distributed in headwaters of the river. There are nine glaciers which cover an area of $22.85 \mathrm{~km}^{2}$. The altitudes of the glacier terminals range from 4360 to $3500 \mathrm{~m}$. The Yushugou River basin is the biggest basin in the region and contains the greatest ice volume among all the river basins in Hami Prefecture (Glacier Inventory of China 1986).

The hydroclimate of the basin is affected by the westerly circulation in summer with $79.6 \%$ of the annual precipitation occurring between May and September. From October to March, the climate is dominated by the Mongolian high pressure (Luo et al. 1999), which results in cold-dry conditions. The average precipitation and temperature at Yushugou Hydrometric Station is $149 \mathrm{~mm}$ and 5.9 (Luo et al. 2002; Zhang and Liu 2011).

\section{Methods}

\subsection{Water sampling}

Water samples used by the study were collected in the river basin in 2013 from April to May (boreal spring). The stable isotope samples included snowmelt water and river water. All water samples were collected using water collectors and stored in $60 \mathrm{ml}$ polyethylene plastic bottles with rubber-seal caps. The samples were frozen and transported to the State Key Laboratory of Cryospheric Science, Cold and Arid Regions 

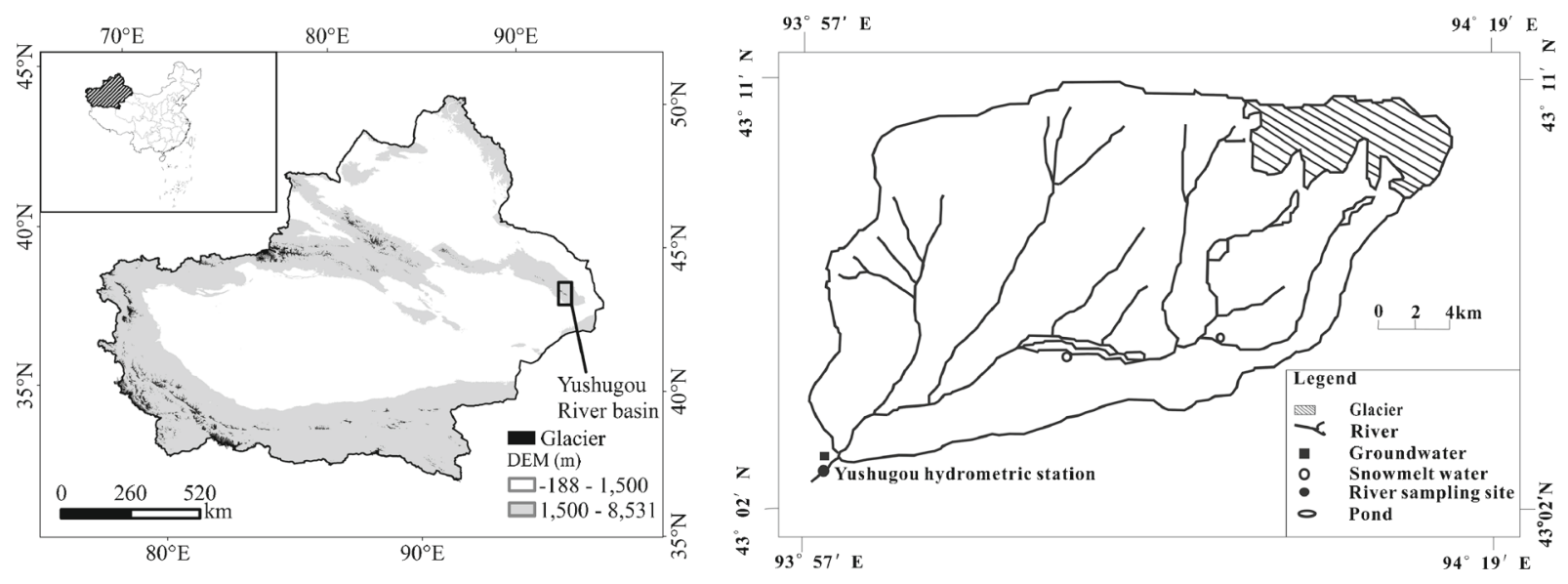

Figure 1. Map showing the study area and locations of sampling sites in the Yushugou River basin.

Environment and Engineering Research Institute. The sampling locations are shown in figure 1 . Sampling details are as follows:

River water samples $(n=27)$ were collected at the Yushugou Hydrometric Station from April 26 to May 2. Daily sampling was conducted to integrated different river flow rates with samples collected at the lowest water level, the highest water level, and the median water level.

Snowmelt samples were collected from the Upper Middle Yushugou River basin. These samples consisted of six snow samples collected from the snow pack.

Groundwater: Seven groundwater samples were collected from a spring near the river.

\subsection{Measurement of $\delta^{18} O$ and $\delta D$}

One of methods to show abundance fractional isotope is expressed in $\delta$ notation. The relative content of ${ }^{18} \mathrm{O}$ and $\mathrm{D}$ were expressed in $\delta^{18} \mathrm{O}$ and $\delta \mathrm{D}$, respectively. The $\delta^{18} \mathrm{O}$ and $\delta \mathrm{D}$ values for the water samples were determined using a liquid hydrogen and oxygen stable isotope analyzer (LGR DLT-100 LWIA) at the State Key Laboratory of Cryospheric Sciences, Cold and Arid Regions Environmental and Engineering Research Institute, Chinese Academy of Sciences. Accuracy of measurement was $\pm 0.5 \%$ for $\delta \mathrm{D}$, and $\pm 0.2 \%$ for $\delta^{18} \mathrm{O}$. The final results were expressed as $\%$ relative to Vienna Standard Mean Ocean Water (V-SMOW, Craig 1961):

$$
\begin{aligned}
\delta^{18} \mathrm{O}= & {\left[\left({ }^{18} \mathrm{O} /{ }^{16} \mathrm{O}\right)_{\text {sample }}-\left({ }^{18} \mathrm{O} /{ }^{16} \mathrm{O}\right)_{\text {SMOW }}\right] } \\
& /\left({ }^{18} \mathrm{O} /{ }^{16} \mathrm{O}\right)_{\text {SMOW }} \times 10^{3} \% \\
\delta \mathrm{D}= & {\left[(\mathrm{D} / \mathrm{H})_{\text {sample }}-(\mathrm{D} / \mathrm{H})_{\text {SMOW }}\right] } \\
& /(\mathrm{D} / \mathrm{H})_{\text {SMOW }} \times 10^{3} \%
\end{aligned}
$$

Results are shown in table 1.
Table 1. Values of $\delta^{18} O$ and $\delta D$ for river water samples during the spring flood period.

\begin{tabular}{llc}
\hline Sampling date/time & $\delta^{18} \mathrm{O}$ & $\delta \mathrm{D}$ \\
\hline 2013.04.26T08:00 & -15.48 & -109.88 \\
2013.04.26T18:00 & -14.85 & -103.88 \\
2013.04.26T22:00 & -14.66 & -104.66 \\
2013.04.26T24:00 & -15.72 & -113.64 \\
2013.04.27T08:00 & -14.92 & -107.05 \\
2013.04.27T16:00 & -14.77 & -104.97 \\
2013.04.27T21:00 & -14.71 & -106.16 \\
2013.04.27T22:00 & -15.4 & -109.37 \\
2013.04.28T08:00 & -15.07 & -113.02 \\
2013.04.28T17:00 & -15.33 & -110.16 \\
2013.04.28T21:00 & -16 & -112.53 \\
2013.04.28T22:00 & -15.87 & -113.82 \\
2013.04.29T08:00 & -15.55 & -109.52 \\
2013.04.29T16:30 & -15.07 & -109.06 \\
2013.04.29T21:15 & -15.41 & -108.56 \\
2013.04.29T23:00 & -15.77 & -113.18 \\
2013.04.30T08:00 & -14.94 & -105.53 \\
2013.04.30T16:30 & -14.84 & -105.68 \\
2013.04.30T21:30 & -14.61 & -103.98 \\
2013.04.30T23:15 & -14.97 & -106.09 \\
2013.05.01T08:00 & -14.82 & -104.10 \\
2013.05.01T17:00 & -14.47 & -101.75 \\
2013.05.01T22:00 & -14.66 & -100.48 \\
2013.05.02T08:00 & -14.98 & -101.93 \\
2013.05.02T16:30 & -14.53 & -98.37 \\
2013.05.02T22:00 & -14.54 & -99.78 \\
2013.05.02T23:10 & -14.3 & -100.79 \\
\hline
\end{tabular}

*Here, the time represents China time.

\subsection{Data analysis}

The $\delta^{18} \mathrm{O} v s$. $\delta \mathrm{D}$ for river, melt, and spring water were compared to the global meteoric water line (GMWL) by bivariate plot. Ideally the data should be compared to the Local Meteoric Water Line (LMWL), which takes into account local climate 
variations, however data for liquid precipitation was not available (Clark and Fritz 1997).

A two-component isotope hydrograph separation based on the steady-state mass balance equations of water and concentration equilibrium (Sklash and Farvolden 1979; Rodhe 1984; Laudon and Slaymaker 1997) was performed to calculate the contribution of different water sources. The twocomponent isotope hydrograph separation method can be expressed as follows:

$$
\begin{gathered}
Q_{t} \times C_{t}=Q_{s} \times C_{s}+Q_{g} \times C_{g} \\
Q_{s}+Q_{g}=Q_{t}
\end{gathered}
$$

where $Q_{t}$ is total river runoff discharge; $Q_{s}, Q_{g}$ are the discharges of components $s, g ; C_{s}, C_{g}$ are the respective concentrations of one observed tracer $s$, $g$; and $s, g$ refer to the two components (snowmelt water and groundwater in this study) of the river water (table 2).

From equations (3) and (4), results can be inferred as follows:

$$
\begin{aligned}
& f_{s}=\frac{Q_{s}}{Q_{t}} \times 100 \%=\frac{C_{t}-C_{g}}{C_{s}-C_{g}} \times 100 \% \\
& f_{g}=\frac{Q_{g}}{Q_{t}} \times 100 \%=\frac{C_{t}-C_{s}}{C_{g}-C_{s}} \times 100 \%
\end{aligned}
$$

where $f_{s}$ and $f_{g}$ represent the contribution rate of snowmelt water and groundwater, respectively.

The application of these equations is discussed by Sklash and Farvolden (1979), Buttle (1994) or Turner et al. (1992). The assumptions are as follows:

- there is a significant difference between tracer concentrations of different components;

- the tracer concentrations do not vary in space and time or any, that the variations can be accounted for;

- there are negligible additional component contributions, or the concentrations must be similar to another component;

- there must be conservative mixing of the tracers;

- the tracer concentrations of the components cannot be collinear.

Table 2. Values of $\delta^{18} O$ and $\delta D$ for groundwater samples during the spring flood period.

\begin{tabular}{lcc}
\hline Sampling date & $\delta \mathrm{D}$ & $\delta^{18} \mathrm{O}$ \\
\hline 2013.04 .26 & -92.86 & -13.10 \\
2013.04 .27 & -90.95 & -13.08 \\
2013.04 .28 & -91.24 & -13.28 \\
2013.04 .29 & -92.97 & -13.51 \\
2013.04 .30 & -94.88 & -13.74 \\
2013.05 .01 & -93.28 & -13.44 \\
2013.05 .02 & -92.83 & -13.25 \\
\hline
\end{tabular}

To calculate the isotope value of snowmelt water for hydrograph separation, we used a method of volume weighted average value (VWA) (Liu et al. 2008a, b). Taking an example ${ }^{18} \mathrm{O}$, the expression of the VMA can be written:

$$
\delta^{18} \mathrm{O}_{e}=\sum_{i=1}^{N} M_{i} \delta^{18} \mathrm{O}_{m \cdot i} / \sum_{i=1}^{N} M_{i}
$$

where $\delta^{18} \mathrm{O}_{e}$ and $\delta^{18} \mathrm{O}_{m \cdot i}$ express the isotope values of the calculation and actual measurement, respectively. $M_{i}$ is the volume of collected snowmelt water. " $N$ " refers to the total number of samples for snowmelt water in our study.

\subsection{Other data sources}

The meteorological data and hydrological data during the sampling period are all observed in Yushugou Hydrometric Station which is affiliated to Hami Hydrology and Water Resources Survey Bureau.

\section{Results and discussion}

\subsection{Hydrology characteristics}

Data from the Yushugou Hydrometric Station spanning 1981-2007 (figure 2) show that both temperature and discharge in the Yushugou River increased from 1981 to 2007. Precipitation decreased in the 1990s relative to 1980 s, but increased from 2001 to 2007. The positive trend in runoff is consistent with the increase in temperature and the resulting increase in snowmelt. Ma and Luo (2009) reported that in the nearby

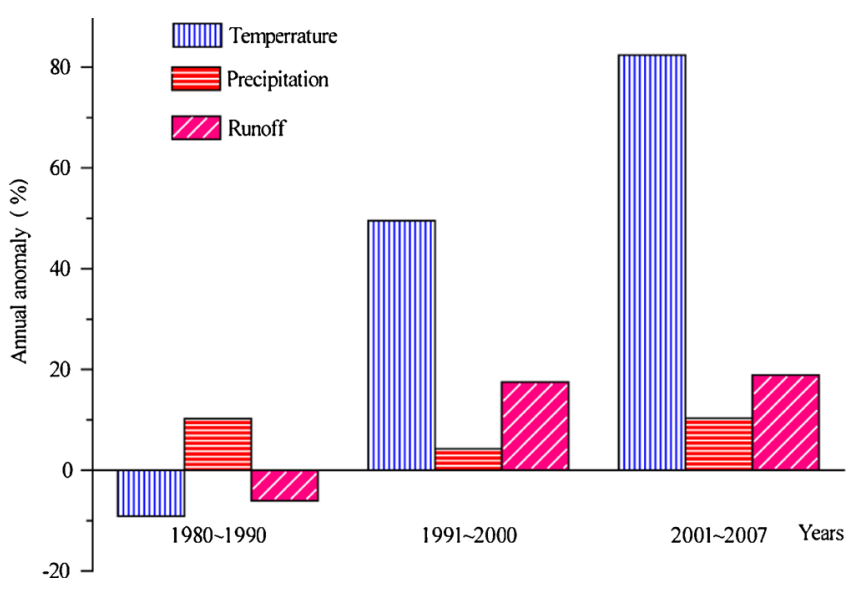

Figure 2. Temperature, precipitation, and runoff anomaly change from 1981 to 2007 at the Yushugou Hydrometric Station. The data is cited from Ma et al. (2009). The anomaly is calculated relative to the 1950-2007 time period. 
Hami district, a positive trend of the river discharge was due to increasing snowmelt water and that other contributions to the river were stable or declining slightly. Similarly, an increase in annual runoff in the Yushugou River basin is associated with rising temperatures in the eastern Tianshan mountain area and is likely due to increased melt (Ma and Luo 2009). In the Yushugou River basin, there are permanent snowpacks and glaciers in the high altitude mountainous area, and seasonal snow in medium to high mountain areas. During late April and early May (i.e., the spring flood), the Yushugou River experiences diurnal changes in flow due to snowmelt water. The size of the diurnal periodicity depends on the size of the mountainous area, snow depth, snow area, glacier characteristics, and temperature (Luo et al. 2002; Zhang and Liu 2011). During this period, there is very little rain to impact runoff. Snowmelt water is the driver between the increased flow and diurnal fluctuations.

\subsection{Characteristics of water stable isotopes and their relationships}

\subsubsection{Characteristics of water stable isotopes}

The composition of the river water hydrogen and oxygen stable isotopes reflect the isotopic composition, mixing ratio of different sources, and evaporation (Yuan et al. 2008). The average $\delta^{18} \mathrm{O}$ and $\delta \mathrm{D}$ values of shallow groundwater near the Yushugou Hydrometric Station were $-13.34 \%$ and $-92.83 \%$ respectively. The values ranged from $-13.08 \%$ to $-13.74 \%$ for $\delta^{18} \mathrm{O}$ and from $-90.95 \%$ to $-94.88 \%$ for $\delta \mathrm{D}$. The lack of variation in the groundwater isotopic values suggests that the groundwater source is relatively stable compared to rapid changes in the surface waters. The $\delta^{18} \mathrm{O}$ values of river water in the basin ranged from $-16 \%$ to $-14.3 \%$ with an average of $-15.08 \%$. The $\delta \mathrm{D}$ values ranged from $-113.82 \%$ to $-98.37 \%$ with an average of $-107.09 \%$ (table 1). Compared to the groundwater, the river water $\delta^{18} \mathrm{O}$ variability was relatively large. Generally, $\delta^{18} \mathrm{O}$ and $\delta \mathrm{D}$ values of river water are stable when groundwater is the primary water source (Su et al. 2009). The variation of $\delta^{18} \mathrm{O}$ and $\delta \mathrm{D}$ in river water and groundwater can therefore reflect the water supply relationship and suggests multiple sources.

In general, $\delta^{18} \mathrm{O}$ values of river water are higher compared to groundwater because of the influence of evaporation (Gremillion and Wanielista 2000). However, Alpine rivers are an exception due to low evaporation rates and rapid discharge. The maximum, minimum, and average $\delta^{18} \mathrm{O}$ and $\delta \mathrm{D}$ values of river water in Yushugou River basin were found to be more negative than that of the groundwater.
The results show and explain if the snowmelt water was more negative with respect to $\delta^{18} \mathrm{O}$ and $\delta \mathrm{D}$ than the river water and that little evaporation had occurred. Indeed the average $\delta^{18} \mathrm{O}$ and $\delta \mathrm{D}$ values of the snowmelt water in the medium to high mountain areas were found to be $-16.11 \%$ and $-114.56 \%$, respectively. From the above study, the $\delta^{18} \mathrm{O}$ and $\delta \mathrm{D}$ of river water were higher than that of snowmelt water and lower than that of groundwater. This hypothesis is further supported by the diurnal fluctuations in the river water isotopic values. No precipitation occurred during the observation period. Thus it is reasonable to assume that the river water was recharged by snowmelt water and groundwater during the sampling period.

\subsubsection{Relationship between $\delta^{18} O$ and runoff}

As shown in figure 3 , the $\delta^{18} \mathrm{O}$ values of river water and the river discharge were anti-correlated and changed on a diurnal basis and throughout the sampling period. From April 26-29 (samples 1-16), snowmelt water runoff dominated the river flow. The daily variation reflects snowmelt water production from daily changes in temperature and insolation. From April 30 to May 2 (samples 1727 ), the snowmelt water runoff began to subside increasing the relative contribution of groundwater into the river. The greater contribution of groundwater increased the $\delta^{18} \mathrm{O}$ values of the river water reducing the daily variability.

\subsubsection{Correlations of $\delta^{18} O$ and $\delta D$ for different waters}

The relationship between $\delta^{18} \mathrm{O}$ and $\delta \mathrm{D}$ of all the samples compared with GMWL is shown in figure 4. The isotopic composition was predominately, above the GMWL (with the exception of

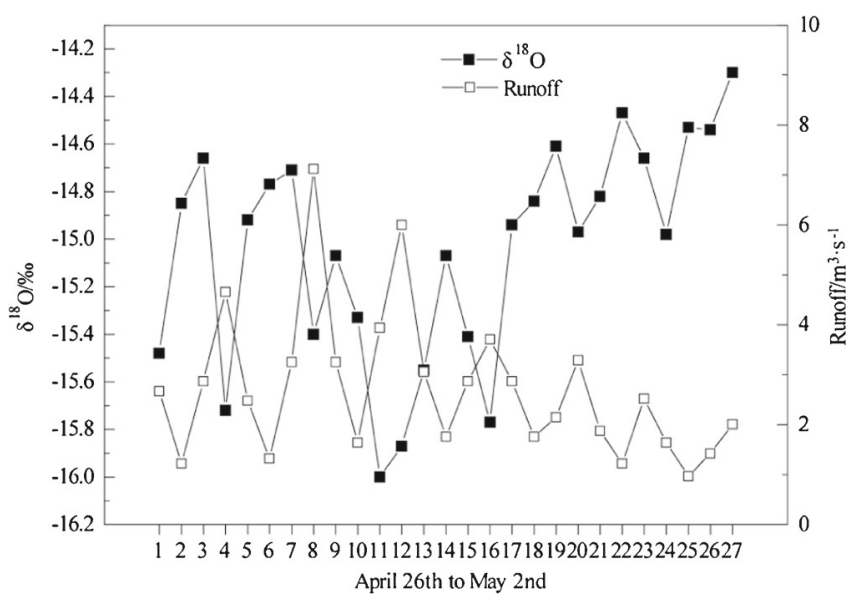

Figure 3. Variation of river water $\delta^{18} \mathrm{O}$ and runoff in Yushugou Hydrometric Station from 26 April to 2 May 2013. 


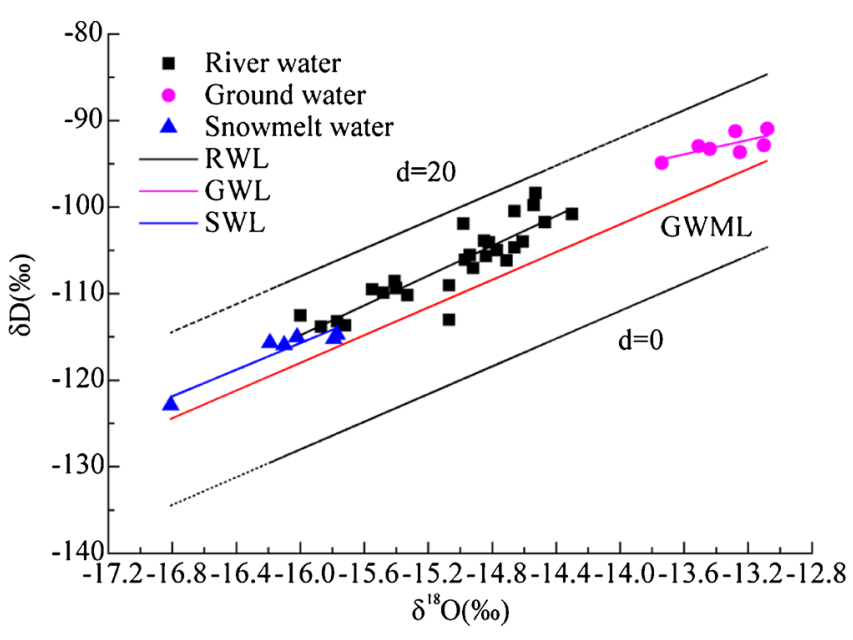

Figure 4. Relation between $\delta^{18} \mathrm{O}$ and $\delta \mathrm{D}$ and deuterium excess values distribution during the spring flood period in Yushugou River basin.

one river water sample). The relationship between $\delta^{18} \mathrm{O}$ and $\delta \mathrm{D}$ values for the river water, groundwater, and snowmelt water was relatively linear with the river water values present between the other two components, similar to Wang (1990). The distance of the river water isotopes to the two components reflects its mixing proportions (Wang 1990). As shown in figure 4, the isotope values of the Yushugou river samples were distributed closer to the snowmelt water than the groundwater suggesting the snowmelt water to be the dominant source (Kong and Pang 2012).

In addition to having more enriched isotope values, the slope of the groundwater $\delta^{18} \mathrm{O}-\delta \mathrm{D}$ relation line (GWL) was gentler than the GMWL (8.0). The slope suggests that the groundwater water experienced some evaporation when it was supplied by snowmelt water and atmospheric precipitation in summer (Gonfiantini 1986). The Yushugou River basin is located in an arid climate zone, which should show an extreme evaporation effect resulting in more negative d-excess values. But, the dexcess value for the groundwater was found to be $\sim 13.89 \%$, above the GMWL. The isotope compositions of the snowmelt water and river water displayed a similar slope to the GMWL, suggesting little evaporation (Gonfiantini 1986; Wang 2013).

\subsection{Hydrograph separation}

\subsubsection{Application of hydrograph separation}

Glaciers and Alpine snowpacks are extremely sensitive to climate change (Watson et al. 1995). Increasing air temperature results in higher snow and glacier melt rates and enhanced surface runoff in Alpine mountain basins. In order to evaluate the impact of climate change, water source contribution estimates over a number of years are required. To evaluate the water source contributions during the study an isotopic hydrograph separation was investigated (Qu et al. 2006). Isotopic hydrograph separations have been investigated for two-component, three-component, and multiplecomponent systems (Hinton et al. 1994; Huth et al. 2004). The Yushugou River basin is a model system to investigate due to the arid environment and lack of precipitation. Based on the reasonable assumption that the river water was only composed of snowmelt and groundwater in spring flood period, a two-component separation was employed. As shown in figure 4, a significant difference exists between the isotopic signatures of the two components reflecting a relatively simple mixing of the components.

Table 3 shows the contribution of snowmelt water and groundwater, resulting from a twocomponent isotope hydrograph separation. At the daily water level maximum, the contribution from snowmelt water varied from $96.1 \%$ to $51.7 \%$, while, the groundwater contribution varied from $48.1 \%$ to $3.9 \%$. At the daily minima, the contribution from snowmelt water ranged from $63.3 \%$ to $36.7 \%$ and the groundwater contribution varied from $63.3 \%$ to $36.7 \%$. The daily contribution variation demonstrates that the injection of snowmelt water caused the daily isotopic fluctuation during spring flood period. On average, $\sim 63 \%$ of the river water originated from snowmelt water and $37 \%$ from groundwater during the 2013 spring flood period.

\subsubsection{Uncertainty in two-component separation}

Evaluation of uncertainty in the isotope separation is as important as the result. To analyze the uncertainty in the hydrograph separation result, a classical Gaussian error propagation technique was applied (e.g., Tipler 1994). Based on error propagation theory, the uncertainty in the hydrograph separation model can be estimated using a first-order Taylor series expansion (Hooper et al. 1990; Genereux 1998). In the case where a parameter $z$ is calculated as a function of several variables $c_{1}, c_{2}, \ldots, c_{n}$ (i.e., $\left.z=f\left(c_{1}, c_{2}, \ldots, c_{n}\right)\right)$, and the uncertainty in each variable is independent of uncertainty in others, the uncertainty in $y$ is related to the uncertainty in each of the variables by the following (Peters et al. 1974; Meyer 1975; Taylor 1982; Kline 1985):

$$
W_{z}=\sqrt{\left(\frac{\partial z}{\partial c_{1}} W_{c_{1}}\right)^{2}+\left(\frac{\partial z}{\partial c_{2}} W_{c_{2}}\right)^{2}+\cdots+\left(\frac{\partial z}{\partial c_{n}} W_{c_{n}}\right)^{2}}
$$


Table 3. Contributions of different waters to the Yushugou River basin from isotope hydrograph separation.

\begin{tabular}{|c|c|c|c|c|}
\hline \multirow[b]{3}{*}{ Sampling data } & \multicolumn{4}{|c|}{ Water level } \\
\hline & \multicolumn{2}{|c|}{ Snowmelt water $(\%)$} & \multicolumn{2}{|c|}{ Groundwater (\%) } \\
\hline & Highest & Lowest & Highest & Lowest \\
\hline 2013.4.26 & 87.0 & 51.8 & 13.0 & 48.2 \\
\hline 2013.4.27 & 76.7 & 54.3 & 23.4 & 45.7 \\
\hline 2013.4.28 & 96.1 & 63.3 & 3.9 & 36.7 \\
\hline 2013.4.29 & 86.9 & 60.0 & 13.1 & 40.0 \\
\hline 2013.4.30 & 51.9 & 36.7 & 48.1 & 63.3 \\
\hline 2013.5.1 & 51.7 & 38.6 & 48.3 & 61.4 \\
\hline 2013.5 .2 & 60.5 & 36.7 & 39.5 & 63.3 \\
\hline Average contribution & \multicolumn{2}{|c|}{62.8} & \multicolumn{2}{|c|}{37.2} \\
\hline
\end{tabular}

Table 4. ${ }^{18} \mathrm{O}$ data used in computing mixing fractions and their uncertainties for river water sample in Yushugou River basin during the spring flood period.

\begin{tabular}{lccrcc}
\hline Water type & Mean $^{\mathrm{a}}$ & $\sigma^{\mathrm{b}}$ & $n^{\mathrm{c}}$ & $t / 70 \% \mathrm{~d}^{\mathrm{d}}$ & $W / 70 \%{ }^{\mathrm{e}}$ \\
\hline Snowmelt water & -16.11 & 0.38 & 6 & 1.156 & 0.44 \\
Groundwater & -13.34 & 0.24 & 7 & 1.134 & 0.27 \\
River water & -15.08 & 0.46 & 27 & 1.058 & 0.49 \\
\hline
\end{tabular}

$\overline{{ }^{a} \text { Mean tracer concentration, } \delta^{18} \mathrm{O} \text { relative to SMOW (standard mean ocean }}$ water) for ${ }^{18} \mathrm{O}$.

${ }^{\mathrm{b}}$ The standard deviation of the samples used to define the mean.

${ }^{\mathrm{c}}$ The number of values used to compute the mean.

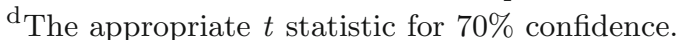

${ }^{\text {e }}$ The propagated uncertainty, equal to the $t$ statistic for $70 \%$ confidence multiplied by the standard deviation of the tracer concentration.

where $W$ represents the uncertainty in the variable specified in the subscript. Application of equation (5-8) gives the uncertainty as follows:

$$
W_{f_{s}}=\sqrt{\begin{array}{c}
\left(\frac{C_{t}-C_{g}}{\left(C_{s}-C_{g}\right)^{2}} W_{c_{s}}\right)^{2}+\left(\frac{C_{t}-C_{s}}{\left(C_{s}-C_{g}\right)^{2}} W_{c_{g}}\right)^{2} \\
+\cdots+\left(\frac{-1}{C_{s}-C_{g}} W_{c_{t}}\right)^{2}
\end{array}}
$$

where $W_{f s}$ represents the total uncertainty in $f_{s}$; $W_{C s}, W_{C g}, W_{C t}$ are the uncertainties of $C_{s}, C_{g}, C_{t}$.

Application to equation (6) would give the same result, since each partial derivative of (6) is simply -1 times the corresponding partial derivative of (5).

From equation (9), it is obvious that a large difference between the tracer concentration of the two components is beneficial. Also, it can be seen that the uncertainty in $f_{s}$ is most sensitive to uncertainty in $C_{t}$, because the multipliers on $W_{c s}$ and $W_{c g}$ differ from the multiplier on $W_{c t}$ by factors of $\left(C_{t}-C_{g}\right) /\left(C_{s}-C_{g}\right)=f_{s}$ and $\left(C_{t}-C_{s}\right) /\left(C_{g}-C_{s}\right)=$ $f_{g}$, respectively; factors whose absolute magnitudes are less than 1 for mixtures of components.

Calculation of uncertainty in hydrograph separations requires tracer concentrations and an estimate of the uncertainty in each. An uncertainty estimation of the contribution of different runoff
Table 5. Separation and uncertainty results for Yushugou River basin during the spring flood period.

\begin{tabular}{lcccc}
\hline \multicolumn{2}{c}{ Mixing fraction (\%) } & & \multicolumn{2}{c}{ Uncertainty } \\
\cline { 5 - 6 } Snowmelt water & Groundwater & & $U_{v}$ & $U_{m}$ \\
\hline 62.8 & 37.2 & & \pm 0.21 & \pm 0.03 \\
\hline
\end{tabular}

$U_{v}$ is uncertainty of hydrograph separation from the spatial and temporal variation of tracer concentrations and $U_{m}$ is uncertainty of hydrograph separation from laboratory analytical error.

components may be caused by the laboratory analytical error due to the measurement of endmember concentrations. In addition, the spatial and temporal variations in the tracer of components may result in significant uncertainty in hydrograph separations (Genereux 1998; $\mathrm{Pu}$ et al. 2012). As for the separation in this study, the temporal variations of $\delta^{18} \mathrm{O}$ were observed for each type of water. The river water and groundwater were sampled only in one site, and the snowmelt water was sampled in two sites. Thus, the general temporal and spatial heterogeneity of $\delta^{18} \mathrm{O}$ should be considered when estimating $W$ values for the components. The standard deviations of the tracer concentrations were multiplied by appropriate $t$ values from the Student's $t$ distribution to estimate 
uncertainty of hydrograph separation from the variation of tracer concentrations $\left(U_{v}\right)$ at the $70 \%$ confidence level (Genereux 1998). Uncertainty from laboratory analytical error can be calculated by the uncertainty in $C_{m}, C_{p}$ and $C_{t}$ from the measurement method. The precision of the measurement method was $0.2 \%$ for the oxygen- 18 analyses, twice of this value was used. On the basis of the assumed standard deviation and the values of $\delta^{18} \mathrm{O}$ in the mixing components, the uncertainty of hydrograph separation from laboratory analytical error $\left(U_{m}\right)$ was evaluated ( $\mathrm{Pu}$ et al. 2012). The estimated uncertainties are shown in tables 4 and 5 . The uncertainty estimates show that the uncertainty in the measurement method $( \pm 0.03)$ is less important than that of the temporal and spatial variations in the tracer concentration $( \pm 0.21)$. The uncertainty terms for the snowmelt water and river water accounted for the majority of the total uncertainty. The isotopic separation for Yushugou river samples is reliable, since the difference between the tracer concentrations greater than the propagated uncertainty (Genereux 1998).

\section{Conclusions}

Based on the Yushugou River basin hydrologic data from 1981 to 2007, the study found that the positive trend in runoff was consistent with increased snowmelt due to rising temperatures. Stable isotope characteristics and the relationship of river water, snowmelt water, and groundwater during the spring flood period show that variations in daily river discharge are due to snowmelt water. Comparing the $\delta^{18} \mathrm{O}$ and $\delta \mathrm{D}$ values of basin waters with the GMWL, it is seen that the river water and snowmelt water have not experienced significant evaporation while the groundwater experienced some evaporation. Using a two-component isotope hydrograph separation model, the river water in the Yushugou River basin was separated into snowmelt water and groundwater during spring flood period. The average water contribution to the catchment during the study is estimated as $\sim 63 \%$ snowmelt water and $37 \%$ groundwater. An important result of the study is that the isotope hydrographic separation gave meaningful results that can be used as the basis of a long-term study. Other river basins in the region should also be investigated to cover an area sufficient to guide sustainable water resource policy.

\section{Acknowledgements}

The authors thank Shufei Luo for helping in samples collection. They also thank engineer Zhu
Yuman of Tianshan Glaciological Station for helping in chemical analysis. This research was supported by the Key Research Program of the Chinese Academy of Sciences (KJZD-EW-G03-01), National Major Science Research Project (973 projects) (2013CBA01801), the National Science Foundation of China (Nos. 41471058, 41171057, 41201065), and foundation for Excellent Youth Scholars of CAREERI, CAS (51Y251B51).

\section{References}

Buttle J M 1994 Isotope hydrograph separations and rapid delivery of pre-event water from drainage basins; Progr. Phys. Geogr. 18 16-41.

Buttle J M 2005 Isotope hydrograph separation of runoff sources; In: Encyclopedia of hydrological sciences (ed.) Anderson M G, Wiley, London, pp. 1-12.

Blume T, Zehe E and Bronstert A 2008 Investigation of runoff generation in a pristine, poorly gauged catchment in the Chilean Andes II: Qualitative and quantitative use of tracers at three spatial scales; Hydrol. Process. 22 3676-3688.

Craig H 1961 Standards for reporting concentrations of deuterium and oxygen-18 in natural waters; Science $\mathbf{1 3 3}$ 1833-1834.

Chinese Academy of Sciences. Lanzhou institute of Glacial Permafrost 1986 China's glaciers directory; Science Press, Beijing.

Clark I D and Fritz P 1997 Environmental Isotopes in Hydrogeology; CRC Press Lewis Publishers, Boca Raton, FL.

Dansgaard W 1964 Stable isotope in precipitation; Tellus 14(4) 436-468.

Dincer T, Payne B R, Florkowski T, Martinec J and Tongiorgi E 1970 Snowmelt runoff from measurements of Tritium and Oxygen-18; Water Resour. Res. 6 110-124.

Fasong Yuan and Miyamoto Seiichi 2008 Characteristics of oxygen-18 and deuterium composition in waters from the Pecos River in American southwest; J. Chem. Geol. 255 220-230.

Fritz P, Cherry J A, Weker K U and Sklash M G 1976 Storm runoff analysis using environmental isotopes and major ions; In: Interpretation of Environmental Isotopes and Hydrochemical Data in Groundwater Hydrology, IAEA: Vienna, pp. 111-131.

Fan Zili and Ma Yingjun 2000 Some issues about the exploitation and the relation utilization of water resources in the arid areas; Arid Zone Res. 17(3) 6-11.

Gonfiantini R 1986 Environmental isotopes in lake studies: Handbook of Environmental Isotope Geochemistry, The Terrestrial Environment (Amsterdam: Elsevier) 2 113168.

Gu Weizu 1993 A case study on the hydrological significance of stable isotope data on alpine catchments with snow cover and glaciers, Xinjiang, China $[\mathrm{C}] / /$ Snow and Glacier Hydrology (Proceedings of the Kathmandu Symposium), IAHS Publication.

Guo Fan, Shangguan Zhiguan and Xia Jin 1994 Determination of components of stormflow using stable isotopes and chemical compositions in Qianshui River of Anhui Province, China; Geochimica 23(1) 42-49.

Genereux D P 1998 Quantifying uncertainty in tracerbased hydrograph separation; Water Resour. Res. 34(4) 915-919. 
Gremillion P and Wanielista M 2000 Effect of evaporative enrichment on the stable isotope hydrology of a central Florida (USA) river; Hydrol. Process. 14 1465-1484.

Harrington G A, Cook P G and Herczeg A L 2002 Spatial and temporal variability of ground water recharge in central Australia: A tracer approach; Ground Water 40(5) $518-528$.

HeYuanqing, Theakstone W H and Yao Tandong et al. 2001 The isotopic record at an alpine glacier and its implications for local climatic changes and isotopic homogenization processes; J. Glaciol. 47(156) 147-151.

Hinton M J, Schiff S L and English M C 1994 Examining the contribution of glacial till water to storm runoff using two and three-component hydrograph separations; Water Resour. Manag. 30 983-993.

Hoeg S, Uhlenbrook S and Leibundgut C 2000 Hydrograph separation in a mountainous catchment-combining hydrochemical and isotopic tracers; Hydrol. Process. 14 1199-1216.

Hooper R P, Christophersen N and Peters N E 1990 Modelling streamwater chemistry as a mixture of soilwater end-members - an application to the Panola Mountain catchment, Georgia, USA; J. Hydrol. 116 321-343.

Huth A K, Leydecker A and Sickman J O et al. 2004 A two-component hydrograph separation for three highelevation catchments in the Sierra Nevada, California; Hydrol. Process. 18 1721-1733.

Kline S J 1985 The purposes of uncertainty analysis; J. Fluids Eng. 107 153-160.

Kendall C 1993 Impact of isotope heterogeneity in shallow systems on shallow system on stormflow generation; Ph.D. Dissertation, University of Maryland, College Park, 310p.

Kendall C and Coplen T B 2001 Distribution of oxygen-18 and deuterium in river waters across the United States; J. Hydrol. Process. 15 1363-1393.

Kong Y L and Pang Z H 2012 Evaluating the sensitivity of glacier rivers to climate change based on hydrograph separation of discharge; J. Hydrol. 434-435 121-129.

Lanzhou Institute of Glaciology and Geocryology Chinese Academy of Science 1986 Glacier Inventory of China(III)Tianshan Mountains (Interior Drainage Area of Scattered Flow in East) [M]; Beijing, Science Press, pp. 69-70.

Laudon H and Slaymaker O 1997 Hydrograph separation using stable isotope, silica and electrical conductivity: An Alpine example; J. Hydrol. 2019(2) 82-101.

Laudon H, Hemond H F, Krouse R et al. 2002 Oxygen18 fractionation during snowmelt: Implications for spring flood hydrograph separation; Water Resour. Res. 38 40.1-40.10.

Liu F D, Xu Z, Wang Z S and Liu S R 2008a Characteristics of water isotopes and hydrograph separation during the wet season in the Heishui River, China; J. Hydrol. 353 $314-321$.

Liu Y H, Fan N J, An S Q, Bai X H, Liu F D, Xu Z, Wang Z S and Liu S R 2008b Characteristics of water isotopes and hydrograph separation during the wet season in the Heishui River, China; J. Hydrol. 353 314-321.

Luo Guangxiao et al. 1999 Analysis on the hydrologic properties of Yiwu River valley; Arid Land Geography (1).

Luo Guangxiao, Ai Li, and Qi Xianming et al. 2002 Hydrological characteristics of the Yushugou Valley; J. Xinjiang Meteorol. 25(5) 19-20, 37.

McDonnell J J, Luo Guangxiao, Ai Li, and Qi Xianming et al. 2002 Hydrological characteristics of the Yushugou Valley; Xinjiang Meteorol. 25(5) 19-20, 37.

Meyer S L 1975 Data Analysis for Scientists and Engineers, John Wiley, New York.

Moser H and Stichler W 1980 Environmental isotopes in snow and ice; Handbook of Environmental Isotope
Geochemistry, 1. Rottedam: Elsevier Scientific Publishing Co., pp. 141-148.

Mast A M, Kendall C and Campbell D H et al. 1995 Determination of hydrological pathways in an alpinesubalpine basin using isotopic and chemical tracers, Loch Vale Watershed, Colorado, USA; IAHS Publ. 228 $263-270$.

Mortathi J, Moraes J M, Rodrigues J C, Victoria R L and Martinelli L A 1997 Hydrograph separation of the Amazon River using ${ }^{18} \mathrm{O}$ as an isotopic tracer; Scientia Agricola 54(3) 167-173.

Ma Xuejuan and Luo Guangxiao 2009 Impact analysis of climate change on runoff in Yushugou river basin; China Water Transport 9(10) 190-193.

Peters D G, Hayes J M and Hieftje G M 1974 Chemical Separations and Measurements: Theory and Practice of Analytical Chemistry, W B Saunders, Philadelphia, Pa, pp. 19-22.

Price R M, Swart P K and Willoughby H E 2008 Seasonal and spatial variation in the stable isotopic composition $\left(\delta^{18} \mathrm{O}\right.$ and $\left.\delta \mathrm{D}\right)$ of precipitation in south Florida; J. Hydrol. 358 193-205.

$\mathrm{Pu}$ Tao and He Yuanqing et al. 2012 Characteristics of water stable isotopes and hydrograph separation in Baishui catchment during the wet season in Mt. Yulong region, southwestern China; Hydrol. Process., doi: 10.1002/hyp.9479.

Qu Simin, Bao Weimin and Shi Peng et al. 2006 Review on isotopic hydrograph separation; Water Resource and Power 24(1) 80-83.

Rodhe A 1984 Groundwater contribution to stream flow in Swedish forested till soil as estimated by oxygen18; In: Isotope Hydrology 1983, IAEA, Vienna, pp. 5556.

Raben P and Theakstone W H 1995 Changes of ionic and oxygen isotopic composition snowpack at the glacier Austre Okstind-breen, Norway; Nordic Hydrol. 29 120.

Sklash M G and Farvolden R N 1979 The role of groundwater in storm runoff; J. Hydrol. 43 46-65.

Song X, Kayane I and Tanaka T et al. 1999 A study of the groundwater cycle in Sri Lanka using stable isotopes; J. Hydrol. Process. 13 1479-1496.

Su Y H, Feng G F and Zhu G F 2009 Environmental isotopic and hydrochemical study of groundwater in the Ejina Basin, northwest China; J. Environ. Geol. 58 601-614.

Taylor J R 1982 An Introduction to Error Analysis: The Study of Uncertainties in Physical Measurements; Univ. Sci. Books, Mill Valley, California.

Tipler P A 1994 Physik. Lehrbuch, Spektrum der Wissenschaften; Spektrum Akademischer Verlag: Heidelberg, Germany.

Theakstone W H and Knudsen N T 1996 Oxygen isotope and ionic concentrations in glacial river water: Multi-year observations in the Austre Okstindbreen basin, Norway; Nordic. Hydrol. 27 101-116.

Turner J, Bradd J and Waite T 1992 Conjunctive use of isotopic techniques to elucidate solute concentration and flow processes in dryland salinized catchments; In: Isotope Techniques in Water Resources Development 1991, IAEA, Vienna, pp. 33-60.

Wang Hengchun 1990 Isotope hydrology geology; Beijing: Geology Publishing House, 1991: 49-50 (in Chinese).

Wang Rongjun 2013 Based on Environmental Isotope Hydrograph Separation during Snowmelt Period-Taking Tianshan Mountains Juntang River basin as an Example; Master's Thesis, Xingjiang University.

Watson R, Zinyowera M and Moss R et al. 1995 Impacts, adaptations and mitigation of climate change: Scientific- 
technical analyses; In: Climate Change 1995 (Cambridge: Cambridge University Press), pp. 248-249.

Yanlong Kong and Zhonghe Pang 2012 Evaluating the sensitivity of glacier rivers to climate change based on hydrograph separation of discharge; J. Hydrol. 434-435 121-129.

Zhang Yinghua, Wu Yanqing and Wen Xiaohu et al. 2006 Application of environmental isotopes in water cycle; $A d v$. Water Sci. 17(5) 738-747.
Zhang Y H, Song X F and Wu Y Q 2008 Use of oxygen18 isotope to quantify flows in the upriver and middle reaches of the Heihe River, northwestern China; Environ. Geol. 58 645-653.

Zhang Hongyan and Liu Hong 2011 Analysis of hydrology and water resources in Yushugou River basin in Xinjiang; Heilongjiang Science and Technology of Water Conservancy 39(5) 8-9.

MS received 31 July 2013; revised 24 June 2014; accepted 7 August 2014 